\title{
Invasive succulents in Southern Western Ghats of Tamil Nadu, India
}

\section{P. Muthulakshmipechiammal and A. Rajendran*}

Phytodiversity Research Laboratory. Department of Botany. School of Life Sciences. Bharathiar University. Coimbatore- 641 046. Tamil Nadu. India. *Email: arajendran222@yahoo.com.

\begin{abstract}
The present article reports a total of 42 invasive succulents identified from Southern Western Ghats. Majority of the species are from Tropical America (14 species), South America ( 9 species), Southern Africa (3 species) and the rest from other countries. A quick inventory and plant identification networks are needed for early detection of naturalized weed in order to control the spread of invasive plant species.
\end{abstract}

Keywords: Invasive succulents; Diversity; Nativity; Southern Western Ghats.

\section{Introduction}

Invasive alien species decreases the diversity of native fauna, flora and ecosystem functions negatively and it changes the composition of native populations and communities. (Elton, 1958; Vitousek, 1986). Convention for Biological Diversity (1992) visualize "biological invasion of alien species as the second worst threat after habitat
Received

September 26, 2018

Accepted

October 21, 2018

Released

December 31, 2018

Full Text Article

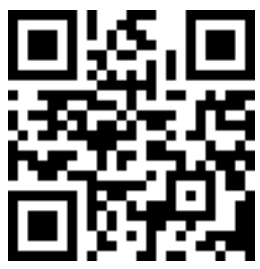

ORCID

(1) 0000-0001-6128-1123

P. Muthulakshmipechiammal

(ㄱ) 0000-0002-7526-3903

A. Rajendran

destruction". Threat to native biodiversity by invasive alien species was greater than environmental pollution and it was assessed as the primary cause of global biodiversity loss (Reddy et al., 2008). On a global scale the potential damage by invasive alien species to native species and ecosystems may be as severe as the impact due to habitat loss and degradation (IUCN 2000). 
The human interference with wild habitats like anthropogenic pressure, commercial trading and environmental reasons could lead to invasion to the new areas (Elton, 1982). After successful local establishment, some naturalized species disperse and produce viable offspring in areas distant from the sites of introduction. Their natural distribution and get introduced to the new ecosystem which has thus increased its spread in the new location, displacing the local biota and threatens native biological diversity (Saxena, 1991; Keane and Crawley, 2002).

A disturbance that affects native flora may reduce the uptake of available resources such as light, water and nutrients, making the surplus resource available to alien invasive species and the site vulnerable to invasion (Davis et al., 2012). Biological invasions may be considered as a form of biological pollution and significant component on human-caused global environmental change and one of the major causes of species extinction. Human-induced disturbances also alter soil properties, thereby affecting recruitment of tropical plants that have low dormancy and are intolerant of adverse soil conditions, while creating opportunities for alien species invasions (Colon and Lugo 2006).

The threat to biodiversity due to invasive alien species is considered second only to that of helical destruction. Invasive species causes loss of biodiversity including species extinction as changes in hydrology and ecosystem feraction. For effective managements to invasive species, knowledge about their ecology, morphology, pharmalogy, reproductive biology, physiology and photochemistry is essential (Raghubanshi et al., 2005)

Worldwide there is a growing catalogue of the potential impacts of invasive species on native species, wildlife habitats, disturbance regimes, and ecosystem services (Pyšek et al., 2011; Simberloff et al., 2013; Foxcroft et al., 2014). According to Raghubanshi
(2005) about $40 \%$ of the species in the Indian flora are alien, of which $25 \%$ are invasive. Many invasive plant species cause economic and/or environmental damage.

The present study is an attempt to identify the alien invasive species of the Southern Western Ghats of Tamil Nadu. Western Ghats is one of the 33 recognized ecologically sensitive zones in the world. The significance of the Western Ghats is that along with its rich biodiversity, it also supports a rich environment-dependent civilization of several thousand years.

\section{Materials and methods}

Several intensive field trips conducted at different seasons during the year 2016-2018. Plant species were collected in their flowering and fruiting stages and detailed field notes were taken on the spot. The attention was paid on the observation of field characters like habit, habitat, flower colour, fragrance and environmental factors that influence its growth and these are entered in the field note book.

The collected plant specimens were identified with the help of the local floras (Gamble, 1915-1936; Nair and Henry, 1983; Matthew, 1991) and available floras, revisions and monographs. Further, authenticated by referring specimens deposited in Madras Herbarium (MH) of Botanical Survey of India, Southern circle, Coimbatore. All the plant species were preserved as herbarium specimens based on the standard instructions (Jain and Rao, 1976). The voucher specimens are deposited in the Herbarium of Department of Botany, Bharathiar University (BUH) Coimbatore.

The nativity of the species is provided based on Matthew (1969), Maheswari and Paul (1975), Nayar (1977), Sharma (1984), Hajra and Das (1982), Saxena (1991), Pandey and Parmur (1994), Reddy et al. (2000), Reddy and Raju (2002), Reddy and 
Reddy (2004), Murthy et al. (2007), Negi and Hajra (2007) and Reddy (2008).

\section{Result and discussions}

The present study was undertaken to appraise the invasive succulent diversity of the Southern Western Ghats. A total of 42 taxa belonging to 40 genera in 25 families were identified from the study area. Majority are generally found in all kinds of ecosystem like forest, waste lands and road sides. They are listed alphabeutically in tabular form followed by Botanical name, name of the family, type of succulents, nativity, life form and habit (Table 1).

Table 1. List of invasive succulent plant species in Tamil Nadu.

\begin{tabular}{|c|c|c|c|c|c|c|}
\hline & Binomial name & Family & $\begin{array}{c}\text { Parts of } \\
\text { succulents }\end{array}$ & Nativity & Life form & Habit \\
\hline 1 & Agave americana $\mathrm{L}$. & Asparagaceae & Leaf & $\begin{array}{c}\text { Central America, } \\
\text { southern North } \\
\text { and northern } \\
\text { South America }\end{array}$ & Shrub & Perennial \\
\hline 2 & Argemone mexicana L. & Papaveraceae & Stem & South America & Herb & Annual \\
\hline 3 & $\begin{array}{l}\text { Alternanthera sessilis } \\
\text { (L.) DC. }\end{array}$ & Amaranthaceae & Leaf & Tropical America & Herb & Perennial \\
\hline 4 & $\begin{array}{l}\text { Alternanthera } \\
\text { philoxeroides (Mart.) } \\
\text { Griseb. }\end{array}$ & Amaranthaceae & Stem & South America & Herb & Perennial \\
\hline 5 & $\begin{array}{l}\text { Amaranthus spinosus } \\
\text { L. }\end{array}$ & Amaranthaceae & Stem & Tropical America & Herb & Annual \\
\hline 6 & $\begin{array}{l}\text { Anredera cordifolia } \\
\text { (Ten.) Steenis }\end{array}$ & Basellaceae & Leaf & South America & Climber & Perennial \\
\hline 7 & $\begin{array}{l}\text { Aptenia cordifolia (L. } \\
\text { f.) Schwantes }\end{array}$ & Aizoaceae & Leaf & southern Africa & Herb & Perennial \\
\hline 8 & $\begin{array}{l}\text { Begonia cucullata } \\
\text { Willd. }\end{array}$ & Begoniaceae & Whole plant & $\begin{array}{l}\text { Brazil and } \\
\text { Argentina }\end{array}$ & Herb & Perennial \\
\hline 9 & Cardamine hirsuta L. & Brassicaceae & Leaf & Trop. America & Herb & Annual \\
\hline 10 & Catharanthus roseus L. & Apocynaceae & Leaf & Trop. America & Herb & Perennial \\
\hline 11 & Callisia repens Jacq. L. & Commelinaceae & Leaf & Mexico & $\begin{array}{c}\text { Creeping } \\
\text { herb }\end{array}$ & Perennial \\
\hline 12 & $\begin{array}{l}\text { Cascabela thevetia (L.) } \\
\text { Lippold }\end{array}$ & Apocynaceae & Leaf & Tropical America & Shrub & Perennial \\
\hline 13 & $\begin{array}{l}\text { Cereus pterogonus } \\
\text { Lam. }\end{array}$ & Cactaceae & Stem & Tropical America & Shrub & Perennial \\
\hline 14 & $\begin{array}{l}\text { Centella asiatica (L.) } \\
\text { Urban }\end{array}$ & Apiaceae & Leaf & $\begin{array}{l}\text { Tropic and } \\
\text { Subtropic } \\
\text { regions } \\
\end{array}$ & $\begin{array}{l}\text { Creeping } \\
\text { herb }\end{array}$ & Perennial \\
\hline 15 & $\begin{array}{l}\text { Crassocephalum } \\
\text { crepidioides (Benth.) } \\
\text { S.Moore }\end{array}$ & Asteraceae & Stem & Trop. America & Herb & Annual \\
\hline 16 & $\begin{array}{l}\text { Crassula multicava } \\
\text { Lem. }\end{array}$ & Crassulaceae & Leaf & South Africa & Herb & Perennial \\
\hline 17 & $\begin{array}{l}\text { Cymbalaria muralis P. } \\
\text { Gaertn. B. Mey.\& } \\
\text { Scherb. }\end{array}$ & Scrophulariaceae & Leaf & Northern Itly & Climber & Perennial \\
\hline 18 & $\begin{array}{l}\text { Cylindropuntia } \\
\text { ramosissima (Engelm.) } \\
\text { F. M. Kunth }\end{array}$ & Cactaceae & Stem & $\begin{array}{c}\text { Northwestern } \\
\text { Mexico, and to } \\
\text { Baja California } \\
\text { and its Islas San } \\
\text { Benito } \\
\end{array}$ & Shrub & Perennial \\
\hline 19 & Datura innoxia Mill. & Solanaceae & Stem & Trop. America & Herb & Perennial \\
\hline
\end{tabular}


Table 1. Continued.

\begin{tabular}{|c|c|c|c|c|c|c|}
\hline & Binomial name & Family & $\begin{array}{c}\text { Parts of } \\
\text { succulents }\end{array}$ & Nativity & Life form & Habit \\
\hline 20 & $\begin{array}{l}\text { Drymaria cordata } \\
\text { Edgew. \& Hook. }\end{array}$ & Caryophyllaceae & Stem & $\begin{array}{c}\text { Mexico, C. } \\
\text { America }\end{array}$ & Herb & Annual \\
\hline 21 & $\begin{array}{l}\text { Eclipta prostrata (L.) } \\
\text { Mant. }\end{array}$ & Asteraceae & Stem & Tropical America & Herb & Annual \\
\hline 22 & $\begin{array}{l}\text { Emilia sonchifolia (L.) } \\
\text { DC. }\end{array}$ & Asteraceae & Leaf & Trop. America & Herb & Annual \\
\hline 23 & $\begin{array}{l}\text { Eichhornia crassipes } \\
\text { (Mart.) Solms. }\end{array}$ & Pontederiaceae & Leaf & $\begin{array}{c}\text { Tropical and } \\
\text { sub-tropical } \\
\text { South America }\end{array}$ & $\begin{array}{l}\text { Free- } \\
\text { floating } \\
\text { herb }\end{array}$ & Perennial \\
\hline 24 & Impatiens balsamina $\mathrm{L}$. & Balsaminaceae & Stem & $\begin{array}{c}\text { India, Southeast } \\
\text { Asia } \\
\text { Southern Africa, } \\
\text { Arabia and South } \\
\text { East Asia }\end{array}$ & Herb & Annual \\
\hline 25 & $\begin{array}{l}\text { Kalachoe delagoensis } \\
\text { Ecklon \& Zeyh. }\end{array}$ & Crassulaceae & $\begin{array}{l}\text { Leaf and } \\
\text { stem }\end{array}$ & $\begin{array}{c}\text { Southern Africa, } \\
\text { Arabia and South } \\
\text { East Asia }\end{array}$ & Herb & Perennial \\
\hline 26 & Martynia annua L. & Martyniaceae & Stem & Trop. America & Herb & Perennial \\
\hline 27 & Mirabilis jalaba L. & Nyctaginaceae & Stem & Tropical America & Herb & Annual \\
\hline 28 & Opuntia stricta Haw. & Cactaceae & Stem & Tropical America & Shrub & Perennial \\
\hline 29 & Pedalium murex L. & Pedaliaceae & $\begin{array}{c}\text { Leaf and } \\
\text { stem }\end{array}$ & Trop. America & Herb & Perennial \\
\hline 30 & $\begin{array}{l}\text { Perisicaria capitata } \\
\text { (Buch.-Ham. ex D. } \\
\text { Don) Gross. }\end{array}$ & Polygonaceae & Leaf & Southeast Asia & Herb & Perennial \\
\hline 31 & Physalis peruviana $\mathrm{L}$. & Solanaceae & Stem & $\begin{array}{c}\text { Tropical South } \\
\text { America }\end{array}$ & Herb & Perennial \\
\hline 32 & Phytolacca octandra L. & Solanaceae & Stem & $\begin{array}{l}\text { Tropical South \& } \\
\text { Central America }\end{array}$ & Shrub & Perennial \\
\hline 33 & $\begin{array}{l}\text { Pilea microphylla (L.) } \\
\text { Liebm. }\end{array}$ & Urticaceae & Leaf & South America & Herb & Annual \\
\hline 34 & Portulacca oleracea L. & Portulacaceae & Whole plant & South America & Herb & Annual \\
\hline 35 & Sonchus asper (L.) Hill & Asteraceae & Leaf & Africa & Herb & Perennial \\
\hline 36 & $\begin{array}{l}\text { Silybum marianum (L.) } \\
\text { Gaertn. }\end{array}$ & Asteraceae & Leaf & $\begin{array}{l}\text { Mediterranean } \\
\text { region (Southern } \\
\text { Europe, Western } \\
\text { Asia and } \\
\text { northern Africa) }\end{array}$ & Herb & Annual \\
\hline 37 & $\begin{array}{l}\text { Taraxacum officinale G } \\
\text {.H. Weber ex Wiggers }\end{array}$ & Asteraceae & Leaf & Eurasia & Herb & Perennial \\
\hline 38 & Tropaeolum majus L. & Tropaeolaceae & Stem & South America & Herb & Perennial \\
\hline 39 & $\begin{array}{l}\text { Tradescantia } \\
\text { fluminensis Vell. }\end{array}$ & Commelinaceae & Stem & South America & $\begin{array}{l}\text { Creeping } \\
\text { herb }\end{array}$ & Perennial \\
\hline 40 & $\begin{array}{l}\text { Tradescantia zebrina } \\
\text { Heynh. ex Bosse }\end{array}$ & Commelinaceae & Leaf \& Stem & Mexico & $\begin{array}{c}\text { Creeping } \\
\text { herb }\end{array}$ & Perennial \\
\hline 41 & $\begin{array}{l}\text { Trianthema } \\
\text { portulacastrum } \mathrm{L} .\end{array}$ & Aizoaceae & Stem & South Africa & $\begin{array}{c}\text { Prostrate } \\
\text { herb }\end{array}$ & Annual \\
\hline 42 & Vinca minor L. & Apocynaceae & Leaf & Europe, W. Asia & Herb & Perennial \\
\hline
\end{tabular}

Succulence is an adaptive strategy that allows plants to remain active diversity seasonal water storage. Succulence is a matter of degree and its expression in envioronmentaly modified in many taxa. They are combination of morphological/anatomical/consideratio ns, ecological condition and physiological aspects (Eggli and Nyffeler, 2009). 
The present study found that Asteraceae is the most specios family (6 species) followed by Amaranthaceae, Apocynaceae, Solanaceae, Commelinaceae and Cactaceae (each have 3 species), Crassulaceae and
Aizoaceae (each have 2 species) and others have single species respectively (Figure 1). The preleminance of Asteraceae species in invasing category shows the high impact of neotropical flora on Indian region (Reddy, 2008).

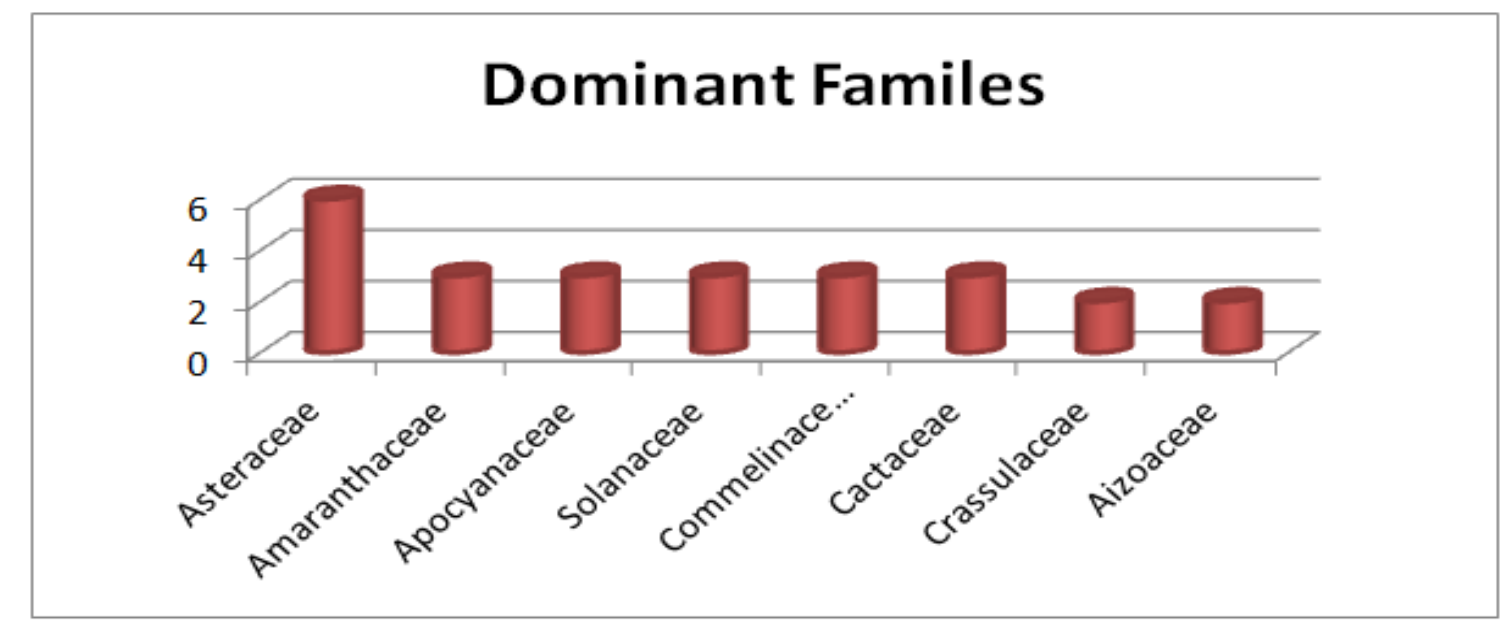

Figure 1. Distribution of invasive succulent taxa of various families in the study area.

The total life forms of the invasive succulent diversity reveals that, herbs are dominant form in which 34 species. It consist of erect herbs (28), creeping herbs (4) prostrate herb (1) and floating herb (1) followed by shrubs with 6 species and climbers have 2 species respectively (Figure 2). All these species reported here were reported as weeds in differ countries or as invasive alien plants in most of the regions. The diversity of their architecture has made them horticultural "Collectibles" form a very early time onwards (Rowley, 1997).

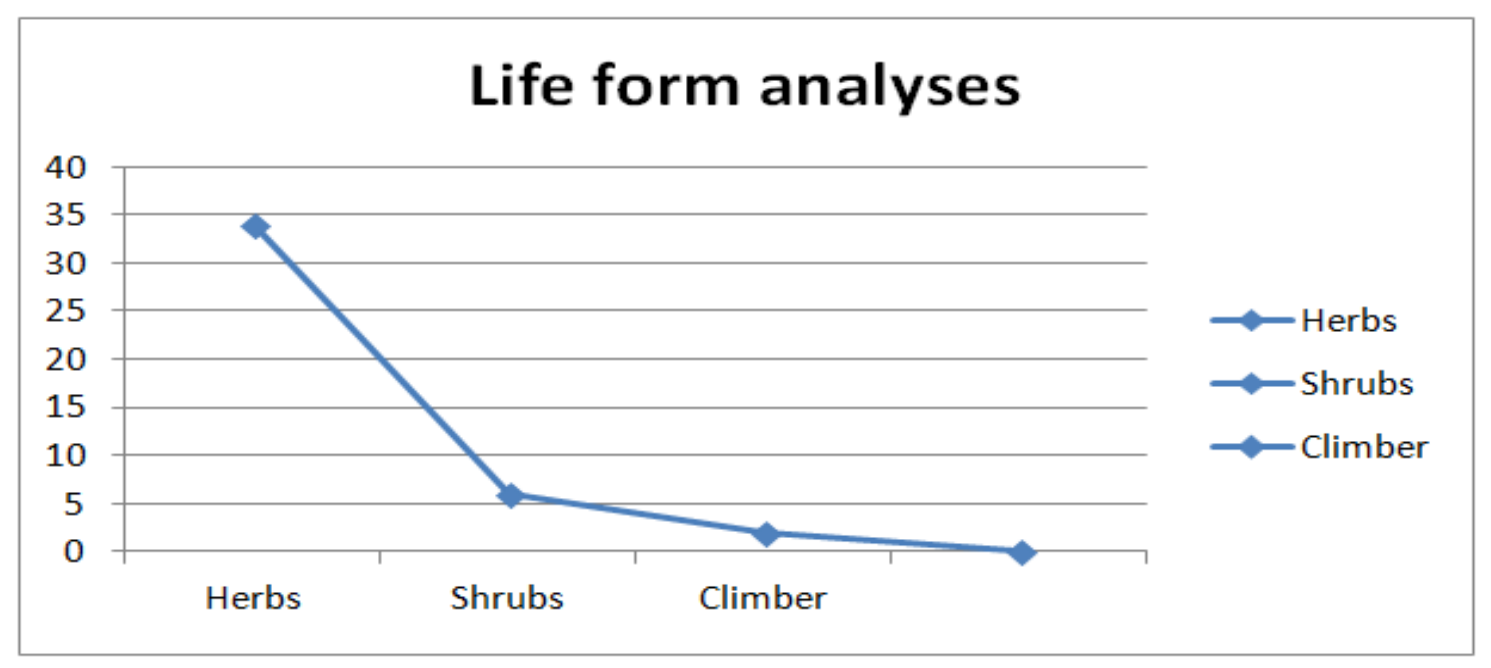

Figure 2. Life form analyses in the study area. 
On the basis of the nativity of the species, a total of 18 different geographical regions were recorded in the present study. In that, about 14 species are native to Tropical America, 9 species are native to South America, 3 species are native to Southern Africa, 2 species are native to Mexico and others have single species in single regions respectively. Almost $80 \%$ of the invasive alien plant species were introduced from Neotropics (Figure 3). It clearly indicators that succulence occur in the subtropics, in a lesser extent, in the tropics and comparatively few representatives are found in temperate and temperate- cool climatic zones (Eggli and Nyffeler, 2009).

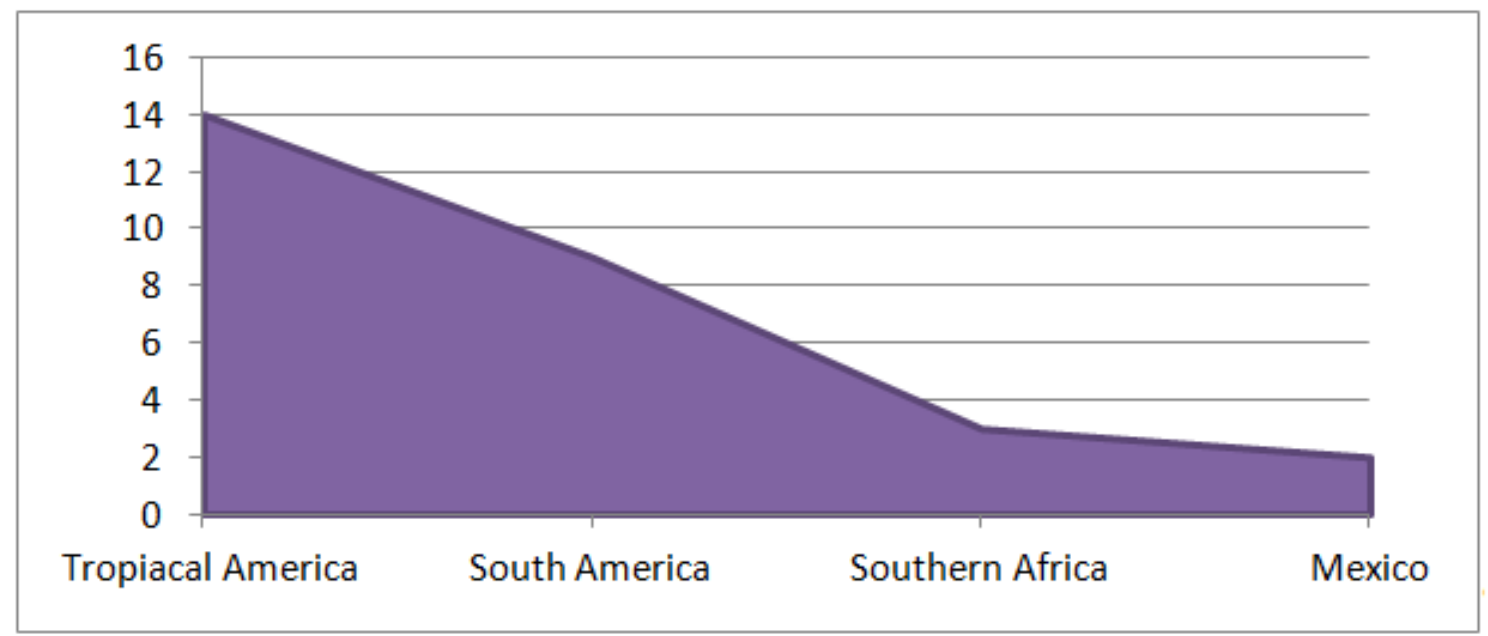

Figure 3. Contribution of different geographical regions to the invasive succulents of study area.

\section{Acknowledgement}

First author is highly thankful to the Professor and Head, Department of Botany, Bharathiar University, for providing necessary facilities to carry out the study.

\section{Conflicts of interest}

Authors declare that they have no conflict of interests.

\section{References}

Aravindhan, V.; Rajendran, A. Diversity of invasive plant species in Boluvampatti forest range, the Southern Western Ghats, India. American-Eurasian Journal of Agricultural \& Environmental Sciences, v. 14, no. 8, p.724-731, 2014. Available from: <https://www.idosi.org/aejaes/jaes14(8)14 /6.pdf>. Accessed on: Jul. 12, 2018.

Adhikari, D.; Tiwary, R.; Barik, S. K. Modelling hotspots for invasive alien plants in India. PLoS One, v. 10, no. 7, e0134665, 2015. https://doi.org/10.1371/journal.pone.01346 65

Colon, S. M.; Lugo, A. E. Recovery of a subtropical dry forest after abandonment of different land uses. Biotropica, v. 38, p. 354364, 2006. https://doi.org/10.1111/j.17447429.2006.00159.x

Davis, M. A.; Grime, J. P.; Thompson, K. Fluctuating resources in plant communities: A general theory of invasibility. Journal of Ecology, v. 88, no. 3, p. 528-53, 2000. https://doi.org/10.1046/j.1365-2745.2000. 00473.x

Eggli, U.; Nuffeler, R. Living under temporarily arid conditions: Succulence as an adoptive strategy. Bradleya, v. 27, p. 13-36, 
2009. https://doi.org/10.25223/brad.n27. 2009.a10

Elton, C.S. The ecology of invasions by animals and plants. London: Methuen, 1958.

Foxcroft, L. C.; Pyšek, P.; Richardson, D. M.; Pergl, J.; Hulme, P. E. The bottom line: Impacts of alien plant invasions in protected areas. In: Foxcroft, L.; Pyšek, P.; Richardson, D.; Genovesi, P. (Eds.). Plant invasions in protected areas. Dordrecht: Springer, 2013. p. 19-41. https://doi.org/10.1007/978-94007-7750-7_2

Gamble, J.S. Flora of the Presidency of Madras. London: Adlard and Sons Ltd., 19151936. v. I-III.

IUCN - International Union for Conservation of Nature. IUCN guidelines for prevention of biodiversity loss caused by alien invasive species. Gland: IUCN, 2000.

Jain, S. K.; Rao, R. R. Handbook of field and herbarium methods. New Delhi: Today and Tomorrow's Printers and Publishers, 1977.

Joshi, A. A.; Mudappa, D.; Raman, T. S. Invasive alien species in relation to edges and forest structure in tropical rainforest fragments of the Western Ghats. Tropical Ecology, 56, no. 2, p. 233-244, 2015. Available from: <http://www.tropecol.com/ pdf/open/PDF_56_2/8 Joshi Mudappa and Raman.pdf>. Accessed on: Jul. 12, 2018.

Keane, R. M.; Crawley, M. J. Exotic plant invasions and the enemy release hypothesis. Trends in Ecology \& Evolution, v. 17, no. 4, p. 164-170, 2002. https://doi.org/10.1016/ S0169-5347(02)02499-0

Matthew, K. M. The flora of the Tamilnadu Carnatic. Tiruchirapalli: Rapinat Herbarium, 1983. Parts 1-3.

Nair, N. C.; Henry, A. N.; Kumari, G. R.; Chithra, V. Flora of Tamil Nadu, India. Coimbatore: Botanical Survey of India, 1983. v. I.

Prasad, E. A. Impact of Lantana camara, a major invasive plant, on wildlife habitat in Bandipur Tiger Reserve, Southern India. Mysore: Nature Conservation Foundation, 2010. Available from: <https://www.rufford. org/files/17.09.06 Detailed Final Report.pdf>. Accessed on: Jul. 12, 2018.

Pyšek, P.; Jarošík, V.; Hulme, P. E.; Pergl, J.; Hejda, M.; Schaffner, U.; Vilà, M. A global assessment of invasive plant impacts on resident species, communities and ecosystems: The interaction of impact measures, invading species' traits and environment. Global Change Biology, v. 18, no. 5, p. 1725-1737, 2012. https://doi.org/ 10.1111/j.1365-2486.2011.02636.x

Raghubanshi, A. S.; Rai, L. C.; Gaur, J. P.; Singh, J. S. Invasive alien species and biodiversity in India. Current Science, v. 88, no. 4, p. 539540, 2005. Available from: <http://www.ias. ac.in/currsci/feb252005/539.pdf >. Accessed on: Jul. 12, 2018.

Reddy, C. S. Catalogue of invasive alien flora of India. Life Science Journal, v. 5, no. 2, p. 84-89, 2008. Available from: <http://www.lifesciencesite.com/lsj/life050 2/16_life0502_84_89_Catalogue.pdf>. Accessed on: Jul. 12, 2018.

Richardson, D. M.; Pyšek, P.; Rejmanek, M.; Barbour, M. G.; Panetta, F. D.; West, C. J. Naturalization and invasion of alien plants: Concepts and definitions. Diversity and Distributions, v. 6, p.93-107, 2000. https://doi.org/10.1046/j.1472-4642.2000. 00083.x

Saxena, K. G. Biological invasion in the Indian sub-continent: Review of invasion by plants. In: Ramakrishnan, P. S. (Ed.). Ecology of biological invasion in the tropics. New Delhi: International Scientific Publications, 1991. p. 53-73.

Simberloff, D.; Martin, J. L.; Genovesi, P.; Maris, V.; Wardle, D. A.; Aronson, J.; Pyšek, P.; Sousa, R.; Tabacchi, E.; Vilà, M. Impacts of biological invasions: What's what and the way forward. Trends in Ecology \& Evolution, v. 28, no. 1, p. 58-66, 2013. https://doi.org/10.1016/j.tree.2012.07.013

Singh, A.; Balodi, K. N.; Naithani, S.; Srivastava, A.; Singh, A.; Kwon-Ndung, E. H. Vascular plant diversity with special reference to invasion of alien species on the Doon University Campus, Dehradun, India. International Journal of Biodiversity Conservation, v. 9, no. 3, p.56-76, 2017. Available from: <https://academicjournals. org/journal/IJBC/article-full-text-

pdf/20A382263038>. Accessed on: Jul. 12, 2018.

Venette, R. C.; Kriticos, D. J.; Magarey, R. D.; Koch, F. H.; Baker, R. H.; Worner, S. P.; Barro, P. J.; Hutchison, W. D.; Fowler, G.; Kalaris, T. M.; Pedlar, J. Pest risk maps for invasive alien species: A roadmap for improvement. BioScience, v. 60, no. 5, p. 349-362, 2010. https://doi.org/10.1525/bio.2010.60.5.5 
Vitousek, P. M.; Walker, L. R.; Whitaker, L. D.; Mueller-Dombois, D.; Matson, P. A. Biological invasion by Myrica faya alters ecosystem development in Hawaii. Science, v. 238, no. 4828 , p. 802-804, 1987. https://doi.org/ 10.1126/science.238.4828.802

Wu, S.-H.; Hsieh, C.-F.; Rejmánek, M. Catalogue of the naturalized flora of Taiwan. Taiwania, v. 49, no. 1, p. 16-31, 2004. Available from: <http://ntur.lib.ntu.edu.tw/ retrieve/168216/05.pdf>. Accessed on: Jul. 12, 2018. 